\title{
Two cases of hydrallantois in the mare
}

\author{
T. v. Oppen and C.-P. Bartmann \\ Clinic for horses, School of veterinary medicine, Hannover
}

\begin{abstract}
Summary
Two mares in the last third of gestation were admitted to the clinic for horses of the School of veterinary medicine in Hannover, because of an abdominal distension and appearent discomfort. In both mares hydrallantois was diagnosed. In the first case abortion was induced and alive twins were delivered with assistance. Both foetuses died shortly after delivery. After recovery and resorption of the ventral oedema a hernia abdominalis was detected. The second mare entered labour spontaneously and needed only little assistance in the delivery of a live foal. This foal was euthanized at day three postpartum because of maladjustment syndrome and poor prognosis. Both mares survived and were discharged a few days later.
\end{abstract}

Keywords: mare, pregnancy, hydrallantois, twin pregnancy, hernia abdominalis

\section{Zwei Fälle von Eihautwassersucht bei der Stute}

Zwei Stuten im letzten Trächtigkeitsdrittel wurden wegen einer deutlichen Umfangsvermehrung des Abdomens und gestörten Allgemeinbefindens in die Klinik für Pferde der Tierärztlichen Hochschule in Hannover überwiesen. Bei beiden Pferden wurde eine Eihautwassersucht diagnostiziert. Im ersten Fall wurde die Geburt eingeleitet und mittels geburtshilflichen Maßnahmen lebende Zwillinge entwickelt. Beide Fohlen verstarben unmittelbar nach der Geburt. Bei dieser Stute wurde nach der Regenerationsphase und Resorption des Bauchödems eine Abdominalhernie festgestellt. Bei der zweiten Stute kam es zu einer spontanen Abfohlung und mit nur wenig Unterstützung zur Geburt eines lebenden Fohlens. Das Fohlen zeigte ein Fehlanpassungsyndrom und wurde am dritten Tag post partum eingeschläfert. Beide Stuten haben überlebt und wurden wieder aus der Klinik entlassen.

Schlüsselwörter: Stute, Trächtigkeit, Eihauwassersucht, Zwillingsträchtigkeit, Hernia abdominalis

\section{Introduction}

In contrast to bovidae, hydrallantois as an excessive distension of the allantoic cavity through fetal fluids is not common in horses (Baier and Berchthold 1981; Allen et al. 1986). Resulting from the extensive enlargement of the uterus, a gross abdominal distension is observed. More or less suddenly this abdominal distension becomes apparent at the last third of gestation in a period of 10 to 14 days (Vandeplassche 1976). At this point the usually multiparous mares show signs of abdominal pain, reluctance to move and especially in the recumbent mare signs of dyspnea (Vandeplassche 1976; Blanchard 1989; Bartmann and Klug 1995). The heart rate increases, but the body temperature remains normal (Roberts 1986; Blanchard 1987). Sometimes the distended uterus fills the abdominal cavity dorsally into the pelvic inlet. In affected mares the amount of fetal fluids can rise up to 40 to 220 liters, in contrast to 10 to 20 liters in the fetal sacs of normal late-gestation mares (Roberts 1986; Vandeplassche 1976; Richter and Götze 1978). The affected mares should be watched intensively for initiation of parturition, as the abdominal contractions are often weak and assistance in delivery is often necessary. Severe complications such as uterine rupture or herniation of the abdominal wall have been reported (Hanson and Todhunter 1986; Clifford et al. 1988). In cattle cases of hydrallantois are often associated with abnormalities of the foetus and are quite common in twin-pregnancies (Vandeplassche et al. 1965).

\section{Case 1}

A seven-year-old multiparous warmblood mare, 9 months pregnant, was admitted to the clinic for horses, School of veterinary medicine in Hannover, because of increasing abdominal size and signs of colic (fig. 1). Presented in the clinic, a large abdomen was detected, together with ventral oedema (fig. 2). The mare was reluctant to move and showed symptoms of dyspnea with a respiratory rate of 48 breaths/min. Rectal examination revealed an enlarged, fluid-filled uterus that bulged dorsally, but no foetus could be detected. A transrectal ultrasonographical examination showed hypoechogenic fluid but no fetus was found. On scanning the ventral abdomen near the midline a living fetus was detected.

On the second day the mare became more restless and uncomfortable, showing increasing dyspnea, sweating and colic. The rectally palpable situation had not changed and elective abortion was induced. Therefore $250 \mathrm{mg}$ of cloprostenol (Estrumate', Fa. Essex, Munich, Germany) were injected into the cervical mucosa and the cervix was manually dilated per vaginam. An intravenous catheter was applied and 18 liters of a balanced polyionic electrolyte solution were administered in the following time. The chorioallantoic membrane was punctured and 70 to 80 liters of allantoic fluid were siphoned gradually. After opening of the amnionic membrane two living fetus were delivered and a further large quantity of fluid escaped. Both, the male and female fetuses weighed $7,5 \mathrm{~kg}$, were both of $56 \mathrm{~cm}$ crownrump length each and hairless (fig. 3). One of them showed a torticollis and both died immediately after delivery.

As retention of the placenta occured, 60 units of oxytocin (Oxytocin Bengen', Fa. WDT, Garbsen, Germany) were administered in physiologic saline solution in slow drip in-travenously and two placentae could be removed shortly afterwards. A lavage of the uterus with warm saline solution was also per- 
formed and repeated the following days, together with an intrauterine antibiotic treatment, applying amoxicillin uterine tablets (Fa. WDT, Garbsen, Germany). As signs of an endometritis occured, the local antibiotic treatment was supported by administration of 10000 units $/ \mathrm{kg}$ penicillin-streptomycin (Omnamycin', Fa. Hoechst Roussel Vet, Unterschleißheim, Germany) intramuscularly. The involution of the uterus was supported by daily intramusculary application of 15 units of oxytocin (Oxytocin Bengen', Fa. WDT, Garbsen, Germany). A low-doseheparinisation (Gerhards 1991) was performed subcutaneously (Heparin-Calcium, Fa. Ratiopharm, Ulm, Germany) to reduce the risk of hypercoagulation and laminitis (Bartmann et al. 2000). Following laxative treatment no more signs of colic appeared. The uterus showed good involution and the mare was discharged with a still persisting ventral oedema.

When the mare was presented in the clinic she weighed 799 $\mathrm{kg}$. The two fetuses and their membranes weighed nearly 40 $\mathrm{kg}$. At the second day post partum the weight of the mare was $635 \mathrm{~kg}$. Therefore the subtracted volume of foetal fluids was approximatedly $124 \mathrm{~kg}$ (124 liters).

Three weeks later the mare was reexamined in the clinic. The uterus could be grasped per rectum and scanning showed no signs of retained fluid in the lumen. A herniation of the abdominal wall was detectable on both sides of the ventral abdomen near to the udder, each one two times big as a fist. The corresponding palpable rent in both abdominal walls was the size of one fist and could be visualized by ultrasound. The abdominal wall around each rent was $40 \mathrm{~mm}$ thick, the wall of the hernia 15 $\mathrm{mm}$. As the position of the udder was more cranial than normal, a partial rupture of the prepubic tendon was discussed. No surgery or supportive means were performed and the mare was discharged again. The owner was informed about the increased risk of rebreeding or riding.

\section{Case 2}

An 11 -year-old multiparous warmblood mare, 10 months pregnant, was admitted to the clinic for horses, School of veterinary medicine in Hannover. The mare appeared uncomfortable, lay in the box and was reluctant to get up. The veterinarian at home was not able to palpate a living fetus and stabilized the horse with infusion before transportation. In the clinic the mare showed no symptoms of colic, but the respiratory rate was increased to 36 breaths/min and the heart beat rate to $68 \mathrm{beats} / \mathrm{min}$. The body temperature was $37,3^{\circ} \mathrm{C}$. At the ventral abdomen an oedema was noticed. There was no oedema of the udder and only a decent swelling of the closed vulva was detected, together with a bloody-viscid discharge.

The rectum was filled with soft faeces and further palpation per rectum revealed a large, fluid-filled uterus, that bulged slightly dorsally containing a palpable living fetus. By vaginal examination, the cervix was found to be dilated to admit 4-5 fingers into the lumen and the foetal membranes could be palpated. At this time the weight of the horse was $918 \mathrm{~kg}$. In the following days the ventral oedema of the abdomen extended from the pectoral region to the udder, nearly 10-15 $\mathrm{cm}$ thick. The respiratory rate decreased to 16-20 breaths/ min, the heart beat rmaintained at a rate of 52-64 beats per minute. Transthoracal ultra-sonographic examination of the heart showed neither a dilatation of the heart nor a fluid-filled pericard. Transabdominal ultrasonographic examination did not show symptoms of an ascites. The detection of the living fetus was complicated by the extensive ventral oedema. In the following two weeks the abdominal distension increased and on rectal palpation the fluid filling of the gravid uterus reached nearly

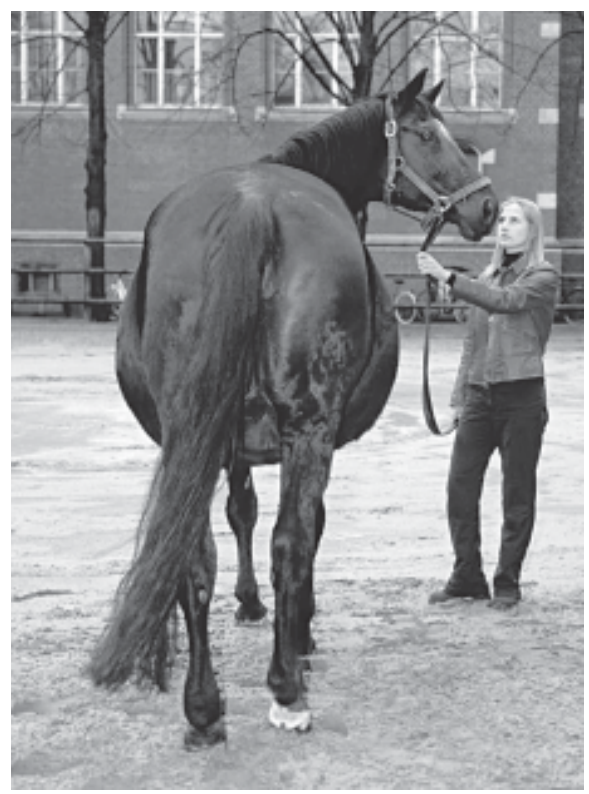

Fig. 1: Grossly abdominal distension (second case) Starke Umfangsvermehrung des Abdomens (zweiter Fall)

into the pelvic inlet of the abdominal cavity. A ballottement of the (living?) fetus was no longer possible. Sero-mucoid discharge of the vulva was detected twice, but there was no change in the almost normal clinical behaviour of the mare.

At the day of the calculated time of birth, the mare showed a little secretion of colostral milk. Meanwhile the bodyweight had increased up to $946 \mathrm{~kg}$. Two days later, the mare became restless and entered labour. With only a little assistance she delivered a living fetus. Unfortunately the large amounts of foetal fluids could not be registered in this short and busy moment. To prevent

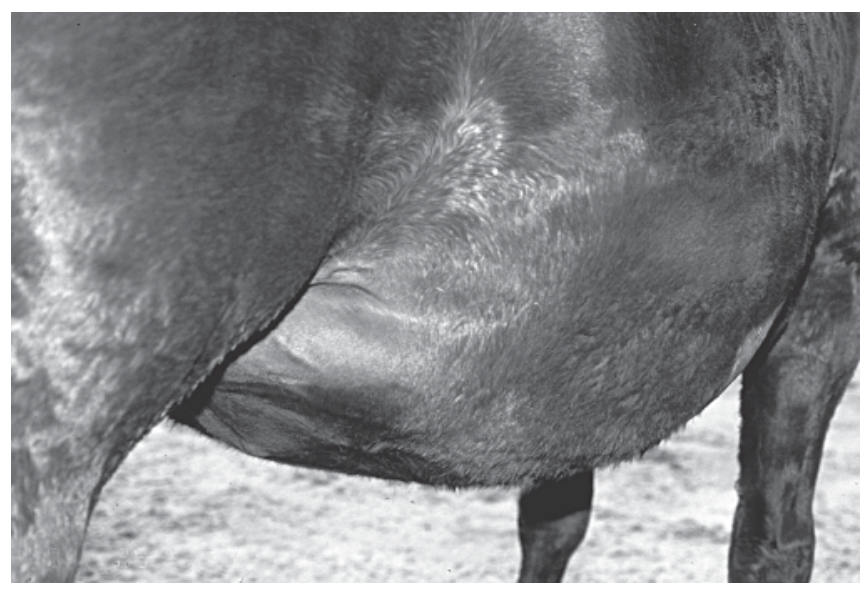

Fig. 2: Excessive ventral edema (first case)

Deutliches Unterbauchödem (erster Fall) 
hypovolemic shock, 15 liters of balanced electrolyte solution were administered intravenously. The mare's condition could be stabilized. As the mare showed symptoms of a retained placenta, 50 units of oxytocin (Oxytocin Bengen), Fa. WDT, Garbsen, Germany) in 1 liter of physiologic saline solution were administered by intravenous drip. To prevent the risk of laminitis and hypercoagulation (Bartmann et al. 2000), also a systemical low-dose-heparinisation (Heparin-Calcium, Fa. Ratiopharm, Ulm, Germany) was performed (Gerhards 1991). The uterus of the mare was subsequently lavaged the next days with warm physiologic saline solution and local antibiotic therapy was performed with amoxicillin uterine tablets (Fa. WDT, Garbesen). Together with an almost normal involution, the recovery of the mare was only distracted by a colic on the second day after giving birth to the foal. An obstipation in the flexura pelvis disappeared by laxative treatment and the mare was discharged a few days later.

The foal showed sypmtoms of maladjustment syndrome and despite intensive care and treatment it's clinical situation worsened. It was euthanized because of a poor prognosis at the third day.

As already mentioned, the mare weighed $918 \mathrm{~kg}$ when admitted to the clinic. Two days before delivery her weight was $946 \mathrm{~kg}$. On the third day postpartum, she weighed $758 \mathrm{~kg}$. The fetus weighed at this time $42 \mathrm{~kg}$, together with the foetal membranes it may have been a weight of $50 \mathrm{~kg}$ at the day of delivery. Therefore the approximate volume of foetal fluids may have been almost $138 \mathrm{~kg}$ (liters).

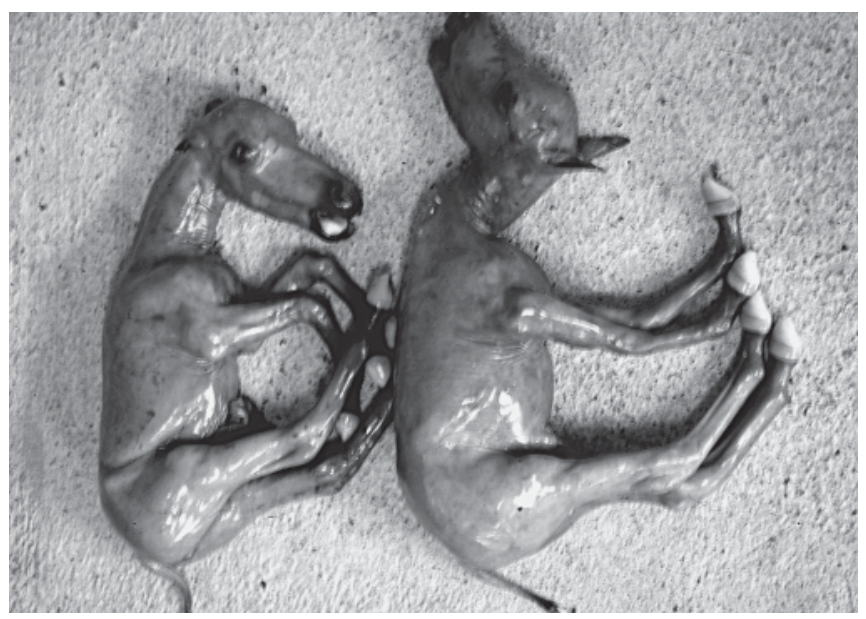

Fig. 3: Fetuses after induced abortion (case 1)

Feten nach induziertem Abort (Fall 1)

\section{Discussion}

The accumulation of abnormal quantities of foetal fluids in the foetal membranes of the mare is a rare condition in horses and is probably always a hydrallantois of which the aetiology remains obscure (Vandeplassche et al. 1976). Only few reports of hydramnion in a mare exist and abdominal enlargement is reported not to be any greater than expected for the state of gestation (Clifford et al. 1988). As in the presented cases, the great increase in abdominal distension, caused by the enlarged uterus, usually occurs in multiparous, late mid to late term mares (810 months), somewhat suddenly over 10 to 14 days.
(Vandeplassche et al. 1976). Wether or not the mare in case one had an extended abdomen for some time prior to the examination in the clinic, because of the twin pregnancy, has to remain unclear. Both mares showed signs of discomfort, dyspnea and colic when admitted to the clinic. In the examination of the mares dropsy of the foetal sacs was considered, as this has been described as a reason for colic in a mare during the last trimester of gestation (Bartmann and Klug 1995). In affected mares, showing a severe ventral oedema accompanied by abdominal distension, herniation of the abdominal wall or even a rupture of the prepubic tendon have to be considered (Hanson et al. 1986; Blanchard 1989; Wöckener and Kind, 1990). In case one a severe ventral oedema was present when the mare was admitted to the clinic. An abdominal herniation was suggested and diagnosed a few weeks after parturition, when the ventral oedema had vanished. The clinical signs of a rupture of the prepubic tendon, such as a sawhorse stand and an elevated tailhead and ischial tuberosities (Roberts 1986), were not found in any case. Mares showing rupture of the prepubic tendon or extensive disruption of the ventral abdominal wall may have to be euthanized (Hanson and Todhunter 1986; Blanchard et al. 1987). The first mare was not euthanized because no discomfort, resulting from the hernia. could be detected. The diagnosis of hydrallantois was confirmed by rectal palpation of a grossly distended uterus (Vandeplassche et al. 1976) and was made in the two cases presented. Hydrallantois was also confirmed in both cases by the total amount of foetal fluids (> 120 and 130 liters) because it greatly exeeded the normal amount of late gestational allantoic fluid ( $<20$ liters) (Vandeplassche et al. 1976). Due to the extensive ventral oedema the transabdominal ultrasonographic examination for the detection of a foetus or even a foetal heartbeat can be complicated (Blanchard 1989). This was only possible in the first mare of this presentation.

Vandeplassche (1976) suggests spontaneous or induced abortion as the only effective treatment of this condition and enumerates retention of the placenta, uterine inertia, circulatory collapse and prolonged involution as possible complications. In both cases presented the circulatory collapse was dealt with by intravenous infusion of balanced electrolyte solution. The retention of the placenta was then treated by a slow drip of oxytocine. In the first mare abortion was induced by local application of prostaglandine and gentle dilatation of the cervix. To decrease the risk of a circulatory collapse the foetal fluids were siphoned gradually, to allow the mare to adjust to fluid loss (Blanchard 1989). In contrast to Vandeplassche (1976) the second mare came into labour spontaneously on time and delivered a living foal with only little assistance, whereas the twins in the first mare had to be delivered because of uterine inertia. The twins died immediately after birth and the foal of the second mare was euthanized three days later because it showed symptoms of maladjustment syndrom despite intensive care and treatment. Concerning the outcome of gestations with hydrallantois, reports differ. None of the foetuses survived in a report by Vandeplassche (1976). Allen (1986) and Blanchard (1987) both report, that one twin was alive, the other already dead, smaller and autolysing. Corresponding to case 2, Blanchard (1986) also notes a living foal, that succumbed in 
spite of intensive care and Allen (1987) describes the case of a foal that died after rupture of the cord. One of the twin-foetuses in the presented cases showed a teratological deformation as reported by different authors (Vandeplassche 1976; Hanson 1986; Waelchli and Ehrensperger 1988). In the presented cases daily uterine lavage was performed in both mares, accompanied by the application of oxytocine during the first days in order to promote the uterine involution. A local - and in case one also systemic - antibiotical treatment was performed to control metritis. Low-dose-heparinisation was performed in both horses in order to reduce the risk of hypercoagulation and laminitis (Bartmann et al. 2000). Both mares showed but a prolonged uterine involution and recovered nearly uneventfully. Against veterinary advice, the first mare was successfully rebred two years later, whereas the owner of the second horse decided not to rebreed with the mare.

\section{Literature}

Allen, W.E. (1986): Two cases of abnormal equine pregnancy associated with excess foetal fluid. Equine Vet. J., 18, 220-222.

Bartmann, C.P. and Klug, E. (1995): Peripartale Kolik bei der Stute. Prakt. Tierarzt, colleg. vet. (XXV), 80-84.

Bartmann, C.P., Kaling, J.S. and Klug. E. (2000): Die Prophylaxe und Behandlung der Geburtsrehe bei der Stute. In: Deutsche Veterinärmedizinische Gesellschaft (Hrsg.), Fachgruppe Fortpflanzung und ihre Störungen, 2. Gießener Tagung über Neonatologie und Jungtierkrankheiten - Fohlen -, Gießen, 29.10.1999, 24-26

Baier, W. and Berchtold, M. (1981): Pathologie der Gravidität. In: Tierärztliche Geburtskunde, 5. Aufl., Hrsg: W. Baier u. F. Schaetz, Enke Verlag, Stuttgart, 55
Blanchard, T.L., Varner, D.D., Buonanno, A.M., Palmer, J.E., Hansen, T.O. and Divers, T.J. (1987): Hydrallantois in two mares. Eq. Vet. Sci., 7, 222-225.

Blanchard, T.L. (1989): Managing the mare with hydrallantois. Vet. Med., 84, 790-792.

Clifford, M.H., Spensly, M.S., Laverty, S. and Blanchard, P.C. (1988): Hydramnion causing uterine rupture in a mare. J. Am. Vet. Med. Ass., 193, 334-336.

Gerhards, H. (1991): Low dose calcium heparin in horses: plasma heparin concentrations, effects on red blood cell mass and on coagulation variables. Equine Vet. J., 23, 37-43

Hanson, R.R. and Todhunter, R.J. (1986): Herniation of the abdominal wall in pregnant mares. J. Am. Vet. Med. Ass., 189, 790-793.

Roberts, S.J. (1986): Veterinary Obstetrics and Genital Diseases. In: Therigeonology, 3rd Ed. S.J. Woodstock, Vt., 277-352.

Vandeplassche, M., Bouters, R., Spincemaille, J. and Bonte, P. (1976): Dropsy of foetal sacs in mares: Induced and spontaneous abortion. Vet. Record, 99, 67-69.

Waelchli, R.O. and Ehrensperger, F. (1988): Two cases of cerebellar abnormality in equine foetuses associated with hydrops of foetal membranes. Vet. Rec., 12, 513-514.

Wöckener, A. and Kind, H. (1990): Hernia abdominalis bei 2 Stuten im peripartalen Zeitraum. Pferdeheilkunde, 6, 137-139.

\section{Dr. Tassilo v. Oppen}

Klinik für Pferde

Tierärztliche Hochschule Hannover

Bischofsholer Damm 15

Haus Nr. 118

D-30173 Hannover

Tel.: 0049-51 1-856 7233

Fax: 0049-51 1-856 7688 